\title{
Feeding Habits of Polynemids: Polydactylus Quadrifilis, Galeoides Decadactylus, and Pentanemus Quinquarius of the Continental Shelf of Grand-Lahou, Côte d'Ivoire
}

\author{
Konan Kouassi Sylvain, \\ Yao Laurent Alla, \\ Oceanological Research Centre, Abidjan, Côte d'ivoire, Abidjan. \\ Amon Yao Nicolas, \\ Universite Péléforo Gon Coulibaly, Korhogo. \\ N'da Konan, \\ Laboratory of Animal Biology and Cytology, \\ Nangui Abrogoua University, Abidjan, Côte d'ivoire, Abidjan.
}

Doi: 10.19044/esj.2018.v14n18p122 URL:http://dx.doi.org/10.19044/esj.2018.v14n18p122

\begin{abstract}
This paper focuses on the threadfins Polydactylus quadrifilis, Galeoides decadactylus, and Pentanemus quinquarius captured by the maritime traditional fishing of Grand-Lahou in Côte d'Ivoire. It aims to determine their feeding habits based on weighing, measuring of body, and intestine height and identification of prey. The specimens of Polydactylus quadrifilis with height lower than $55 \mathrm{~cm}$ have an average of $12 \pm 1$ intestinal filaments, whereas those of height higher than $100 \mathrm{~cm}$ have an average of $20 \pm 2$ of them. This average is constant concerning Galeoides decadactylus (12 \pm 2$)$ and Pentanemus quinquarius (11 \pm 2$)$, for all height. The specimens of Polydactylus quadrifilis consume mainly fish (74.45\%), followed by shrimps $(10.06 \%)$. The juvenile ones of less than one year prefer shrimps $(80.28 \%)$, whereas fish are preferred (87.07) by the older individuals. Whatever their age, Galeoides decadactylus and Pentanemus quinquarius mainly consume shrimps in the ratio of $83.11 \%$ and $68.75 \%$ respectively. The relative yearly food consumption reveals for Polydactylus quadrifilis a quantity of 0.124 $\mathrm{T} / \mathrm{Km}^{2}$ /year, whereas that of Galeoides decadactylus is $0.02 \mathrm{~T} / \mathrm{Km}^{2} /$ year. As for the specimens of Pentanemus quinquarius, they consume 0.013 $\mathrm{T} / \mathrm{Km}^{2} /$ year. Threadfins have very short intestine $(\mathrm{IC}<1)$ relatively to the intestinal coefficient. Their food habit is relating to stomach and intestine capabilities.
\end{abstract}


Keywords: Threadfin, diet, Polydactylus quadrifilis, Galeoides decadactylus, Pentanemus quinquarius

\section{Introduction}

The current captures of fishing are almost equivalent to the tenable maximum production of the halieutic stock of the littoral of Côte d'Ivoire (FAO, 2008). These fishing unload, amongst others, Polynemids composed of three genera: Polydactylus, Galeoides, and Pentanemus. The Polydactylus genus is represented by the Polydactylus quadrifilis species on West African coasts. In the same way, the genera Galeoides and Pentanemus are represented by the species Galeoides decadactylus and Pentanemus quinquarius respectively on these coasts (Motomura et al., 2002).

Lalèyè (2004) affirms that naturalists, scientists, and the persons in charge of the development have been concerned with the knowledge of the ichthyologic fauna of rivers and African waters for a few years. This interest is due to two principal reasons:

1 - By virtue of its richness, the ichthyologic fauna of Africa offers the broadest and most complex fields of investigation that leads to the attachment of the scientists to this wide natural laboratory.

2- The exploitation of fresh, brackish water and marine fish of Africa, by local permanent increasing populations, becomes more and more intense. In addition, there is especially the alarming acceleration of the overall process of degradation of the natural environment that is a major risk for regression and extinction of species. According to Du Buit (1996), the study of the stomach contents of predators reveals some information that helps in the comprehension of the modes for the use of the resources, the competitions inter and intraspecific, and the adaptability of these fish in their environment. The knowledge of these feeding modes makes it possible to understand the influence of big predators on the abundance and the recruitment of the other marine organisms within the framework of the estimation of the long-term impacts of the fishing activities on the maritime coasts. In the same way, the study of the feeding modes of various species of an aquatic environment allows the comprehension of the functioning and the diet organization of this ecosystem (Cruz-Escalona et al., 2000). Very limited information has been made available on the feeding habits of this species, and the difficulty that previous authors studying food habits of deep-sea fish encountered was extremely high incidence of averted stomachs and those with regurgitated contents due to decompressed gas bladders (Jones, 2008).

This study is a contribution to the knowledge of the threadfin's diet behaviors which will permits to have informations on the diet method of these fishes. 


\section{Materials And Methods}

The biological material used is the three species of threadfins: Polydactylus quadrifilis Galeoides decadactylus, and Pentanemus quinquarius. Fishes were collected through monthly samplings of the unloading of maritime artisanal fishing by the purse seine of Grand-Lahou. The sampling rates extend from May 2009 to April 2011. The sample includes 534 specimens of Polydactylus quadrifilis, 648 Galeoides decadactylus, and 453 Pentanemus quinquarius. The fish were measured with a tape measure and weighed using precision balances of $1 / 10 \mathrm{~g}$ and $1 \mathrm{~g}$. For each individual examined, the total length (Lt) to the nearest centimeter, the livebait and eviscerated weight of the fish to the nearest gramme were taken down. An incision on the abdomen of the fish was done resulting to the permission of removing the digestive tract. It is then preserved in a $10 \%$ formalin solution during 72 hours. The stomach contents were rinsed with a $70 \%$ alcohol solution dried with blotting paper and observed using a binocular microscope (Olympus SZ 30).

\section{Digestive System and Diet of Threadfins}

In addition to the usual digestive system organs of animals, the digestive system of threadfins includes the intestinal filaments. These ones were counted on each fish in order to estimate their number according to the size of fish. Prey items were identified with the identification keys of Fischer et al. (1981), Bellemans et al. (1988), Schneider (1990), Bouchon (1997), Défaye (1998), and of Tachet et al. (2003). Once identified, the prey are counted manually and weighed to the nearest $1 / 100 \mathrm{~g}$.

Diet are determined through the calculation of the parameter of the index of relative importance (IRI) per each preys family, which are numerical, weigh and occurrence percentages (Pinkas et al., 1971). The formula follows.

\section{Numerical Percentage}

$$
\mathrm{N}=\frac{\text { Total individuals numbers of the prey " } \mathrm{i} \text { " }}{\text { Total numbers of inventoried preys }} \text { X100 }
$$

Weigh Percentage

$$
\mathrm{W}=\frac{\text { Total weight of the prey " } \mathrm{i} \text { " }}{\text { Total weight of inventoried preys }} \mathrm{X} 100
$$

Percentage of Occurrence 


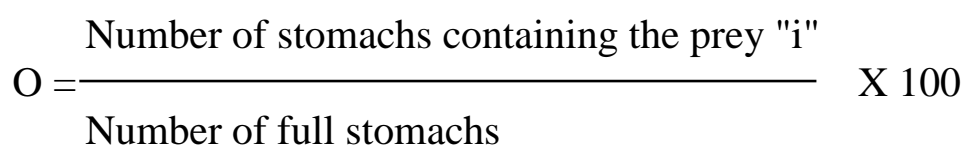

The trophic strategies are studied starting from the specific index of abundance and the percentage of occurrence of preys observed in the stomachs of each Polynemid family.

The specific index of abundance $(\mathrm{Si})$, which indicates the interest that the fish grant to the preys that they consume (Amundsen et al. 1996), has the following formula:

$\mathrm{Si}=\mathrm{ai} / \mathrm{a} \times 100$

ai: mass of food category "i"

a: total mass of the preys in the stomachs containing prey "i"

The values obtained were used to establish the diagrams of Amundsen of the three species of threadfins with the STATISTICA 7.1 software. The trophic strategy which can either be specialized, or generalized or both simultaneously, are given starting from these diagrams.

\section{Food Consumption Estimate}

Du Buit (1987) and Jones (1978) affirmed that the consumption of food is estimated using a formula which takes into account the speed of digestion according to the temperature and the quality of food. The equation of consumption is:

$$
\mathrm{C}=\mathrm{Q}\left(\frac{L t}{40}\right)^{1.4} W^{0.46}
$$

$\mathrm{C}$ is the consumption in grams per hour; $\mathrm{Q}$ : the specific coefficient of digestibility depending on the temperature and the type of food; Lt: the total length of the individuals $(\mathrm{cm}), \mathrm{W}$ : the average weight $(\mathrm{g})$ of the food observed in the stomachs. Calculations are carried out by classes of height every 24 hours. The length selected is the total length $(\mathrm{Lt})$ of the specimens sampled in each class. The values of the coefficient of digestibility $(0.18<\mathrm{Q}<0.20)$ corresponds to the experimental data of Jones (1978) for fish in "feed continuously" i.e., nourished every day at a temperature ranging between 9 and $11{ }^{\circ} \mathrm{C}$. The approximate values of $\mathrm{Q}$ according to the recorded temperatures $\left(22^{\circ}-29^{\circ} \mathrm{C}\right)$ give $0.44<\mathrm{Q}<0.527$.

Furthermore, the daily consumption $\mathrm{C}$ is then expressed according to the weight of the body $\mathrm{P}(\mathrm{g})$ :

$$
\mathrm{C}=\mathrm{aP} \text {. } \quad \mathrm{a} \text { and } \mathrm{b} \text { are parameters linking } \mathrm{C} \text { to } \mathrm{P} \text {. }
$$

The relative yearly consumption of food $\mathrm{Q} / \mathrm{B}$, i.e. the consumed quantity Q per unit of biomass B was evaluated by Palomares and Pauly (1989) through the mathematical expression stated below: 
$\mathrm{Q} / \mathrm{B}=\int_{t r}^{t m a x} \frac{\frac{d w \times N t}{d t}}{K 1(t)} / \int_{t r}^{t m a x} W t N t d t$

$\mathrm{Nt}=$ number of fish at age $t$,

$\mathrm{Wt}=$ weight $(\mathrm{g})$ at age $t$,

$\mathrm{K} 1(\mathrm{t})=$ coefficient of food conversion at age $t$,

$\operatorname{tr}=$ age $($ year-1) of recruitment in the population considered, and tmax $=$ maximum observed age $($ year-1).

For this study, the following recent predictive model of Palomares and Pauly (1998) was used:

$\log (\mathrm{Q} / \mathrm{B})=5.847+0.280 \log \mathrm{Z}-0.152 \log \mathrm{W}_{\infty}-1.360 \log \mathrm{T}^{\prime}+0.062+0.510$ $\mathrm{h}+0.390 \mathrm{~d}$.

In addition, the decimal logarithm of the various parameters was used also.

$\mathrm{Z}$ : total mortality;

$\mathrm{Q} / \mathrm{B}$ : required quantity;

$\mathrm{W}_{\infty}$ : the asymptotic fresh weight (in grams) for the studied population;

$\mathrm{T}^{\prime}$ : a parameter integrating the annual average temperature $\left({ }^{\circ} \mathrm{C}\right)$ of the studied environment. The parameters $\mathrm{h}$ and $\mathrm{d}$ (and not their decimal logarithm) explain the feeding mode: $\mathrm{h}=1 ; \mathrm{d}=1$ (Villanueva, 2004).

\section{Fish Height- Length of Intestine Relationship}

Fish have several types of morphological specializations respectively adapted to diet and precise modes of collection of prey. These modifications concern mainly the morphology of the head and the mouth, then the length of the intestine, and the shape of the body which determines the agility, the power, and the speed of the fish (Paugy \& Lévêque, 1999). The equation helps to establish a conversion between certain metric parameters, and the total length of fish was applied to the threadfins in order to determine the relation between their total length ( $\mathrm{Lt}$ ) and the length of the intestine. In the same way, the intestinal coefficient (IC) was calculated for each specimen with the following formula (Paugy, 1994):

$\mathrm{IC}=\frac{L I}{L S}$

$\mathrm{Li}=$ length of the intestine, $\mathrm{Ls}=$ standard length of fish.

\section{Jaccard Community Index (Sj)}

The Jaccard community index allows the analysis of data between specimens from different media and an inter- and intra-specific comparison of diets of different species (Douglas, 1984). Its formula is as follows: 
$\mathrm{Sj}=\mathrm{c} /(\mathrm{a}+\mathrm{b}-\mathrm{c})$

A: total number of prey categories in the feeding of species $\mathrm{X}$

B: total number of prey categories in the diet of the species $y$

$\mathrm{C}$ : total number of prey categories common to species $\mathrm{x}$ and $\mathrm{y}$.

Douglas (1984) and Doumbia (2003) noted that the food similarity between two species of fish may occur in the following cases:

- if $\mathrm{Sj}>0.7$, there is a strong similarity between the diets of two fish

- if $0.5<\mathrm{Sj}<0.7$, the similarity is average

- if $\mathrm{Sj}<0.5$, the similarity between diets is low

\section{Results}

\section{Digestive System and Diet of Threadfins}

The number of the intestinal filaments of Polydactylus quadrifilis varies with their size. Thus, the juvenile, size lower than $55 \mathrm{~cm}$ have the average of $12 \pm 1$ filaments and those of size close to $86 \mathrm{~cm}$, have $15 \pm 1$ filaments. Concerning the adults, this average is $18 \pm 1$ for those whose height are up to $96 \mathrm{~cm}$ and $20 \pm 2$ filaments when the size is higher than $100 \mathrm{~cm}$. However, the average of these filaments is constant for the specimens of Galeoides decadactylus (12 \pm 2 ) and Pentanemus quinquarius (11 \pm 2 ) at all size.

The weigh percentages of all the prey consumed by the specimens of Polydactylus quadrifilis (Figure 1a) indicates a great prevalence of fish $(74.45 \%)$, whose most frequent species are Clupeidae $(61.73 \%)$. The shrimps $(10.06 \%)$ come after with their principal families, Peneidae, Palaemonidae, and Aristeidae. According to the specific index of abundance, Soleidae (12.75\% Si), Claroteidae (7.60\% Si), and crabs (Portunidae, 12.35\% Si) are most observed in their stomachs, with Penaeidae shrimps $(6.83 \% \mathrm{Si})$ (Table I). However, the shrimps constitute at $80.28 \%$, the preferential prey for the juveniles of Polydactylus quadrifilis of height lower than $45 \mathrm{~cm}$, corresponding to an age lower than one year ( Konan et al., 2012), whereas fish account for $19.71 \%$. The fish are preferred by the specimens of Polydactylus quadrifilis $(87.07 \%)$ of more than $46 \mathrm{~cm}$, corresponding to an age of one year and over, to the detriment of shrimps (12.92\%). The preys of Galeoides decadactylus and Pentanemus quinquarius are mainly dominated at all age by shrimps, respectively at $83.11 \%$ and $68.75 \%$ (Figure $1 \mathrm{~b}$ and Figure 1c). As for the specimens of Galeoides decadactylus, the principal families of shrimps prey are Penaeidae (75.52\% IRI) and Palaemonidae (6.27\% IRI). Penaeidae (11.33\% Si) and Lysiosquillidae (12.48\% Si) are most consumed relatively to the specific index of abundance (Table II). Concerning those of Pentanemus quinquarius, their preferential preys are Penaeidae (72.57\% IRI) and Aristeidae (11.26\% IRI). According to the specific index of abundance, Pandalidae (16.85\% Si), Pasiphaeidae (10.37), and Octopodidae 
$(15.70 \% \mathrm{Si})$ are most consumed (Table III). The trophic strategies of the threadfins are illustrated by the diagrams of Amundsen (Figure 2). These diagrams indicate that the specimens of these fish have specialized diet in the majority prey which constitutes their basic food. However, a small proportion of the other preys are occasionally included in the diet of some individuals.

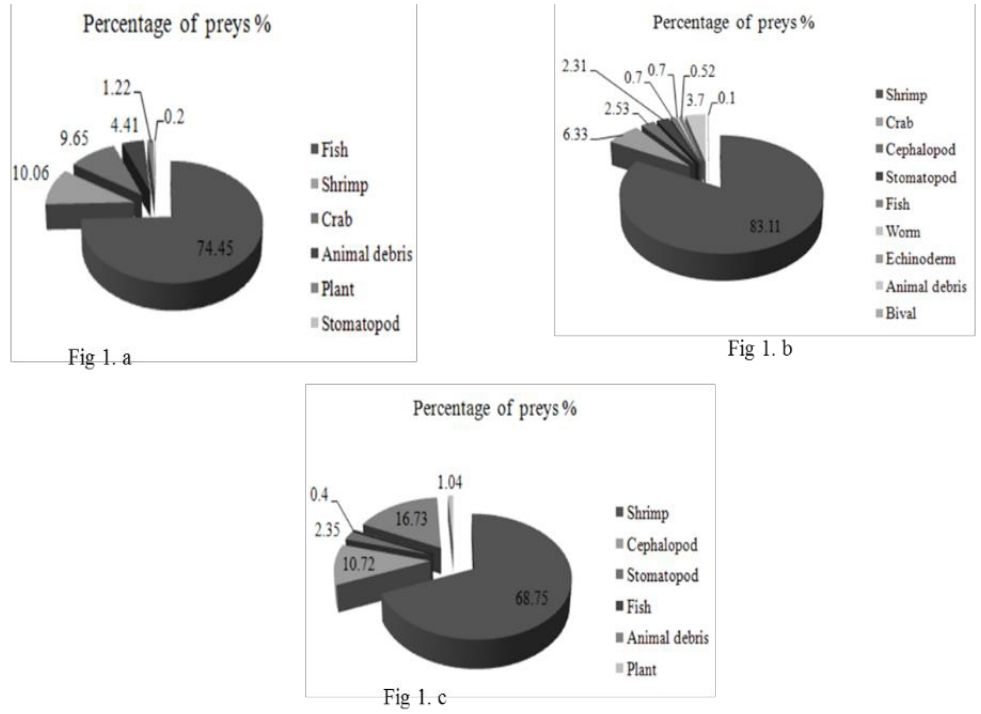

Figure 1. Percentage of the weights of all the prey observed in the stomachs of Polydactylus quadrifilis (1 a), Galeoides decadactylus (1 b) and Pentanemus quinquarius (1 c)

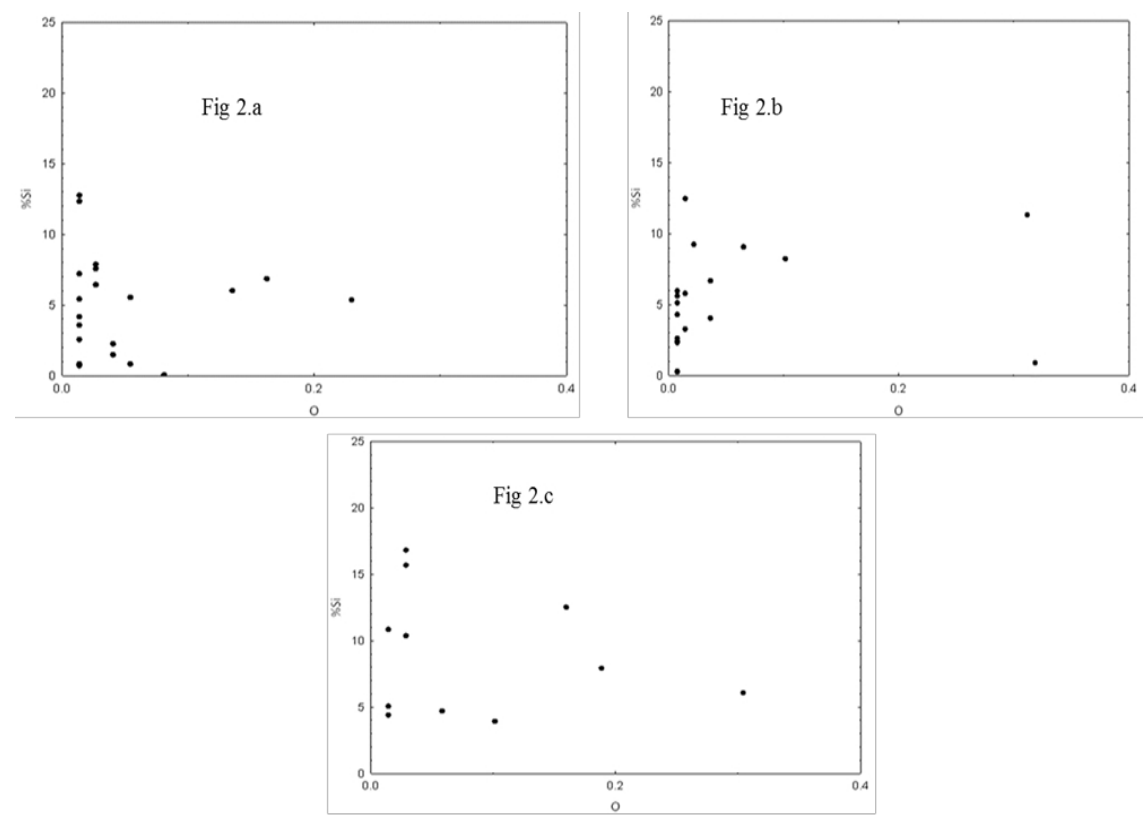

Figure 2. Diagrams of Amundsen showing the feeding strategy of Polydactylus quadrifilis (2 a), Galeoides decadactylus (2 b) and Pentanemus quinquarius (2 c). A plot of the specific index of abundance $(\% \mathrm{Si})$ in terms of the percentage of occurrence $(\mathrm{O})$. 
Table I. Diet of Polydactylus quadrifilis. Percentage of occurrence (O), Numerical percentage $(\mathrm{N})$, Weigh percentage $(\mathrm{W})$, index of relative importance (IRI) and specific index of abundance $(\mathrm{Si})$ of prey families.

\begin{tabular}{llllllll}
\hline Family & $\mathrm{O}$ & $\mathrm{N}$ & $\mathrm{W}$ & $\mathrm{Si}$ & $\% \mathrm{Si}$ & $\mathrm{IRI}$ & $\% \mathrm{IRI}$ \\
Aristeidae & 5.40 & 4.03 & 0.29 & 42.36 & 5.52 & 23.37 & 0.94 \\
Palaemonidae & 5.40 & 7.26 & 0.65 & 6.59 & 0.86 & 42.76 & 1.73 \\
Penaeidae & 16.21 & 18.54 & 7.28 & 52.43 & 6.83 & 418.87 & 16.95 \\
Solenoceridae & 4.05 & 2.42 & 0.98 & 11.40 & 1.48 & 13.82 & 0.56 \\
Crangonidae & 1.35 & 1.61 & 0.11 & 19.82 & 2.58 & 2.33 & 0.09 \\
Sicyioniidae & 1.35 & 0.80 & 0.37 & 32.11 & 4.18 & 1.60 & 0.06 \\
Nematocarcinidae & 1.35 & 0.80 & 0.28 & 6.36 & 0.83 & 1.48 & 0.06 \\
Portunidae & 1.35 & 1.61 & 9.55 & 94.80 & 12.35 & 15.09 & 0.61 \\
Soleidae & 1.35 & 0.80 & 0.86 & 97.82 & 12.75 & 2.25 & 0.09 \\
Sqillidae & 4.05 & 2.42 & 0.20 & 17.28 & 2.25 & 10.62 & 0.43 \\
Clupeidae & 22.97 & 28.22 & 38.16 & 41.16 & 5.36 & 1525.17 & 61.73 \\
Citharidae & 1.35 & 0.80 & 0.43 & 27.27 & 3.55 & 1.67 & 0.06 \\
Muraenesocidae & 2.70 & 1.61 & 10.67 & 49.42 & 6.44 & 33.20 & 1.34 \\
Chrisistich sp & 2.70 & 1.61 & 24.32 & 58.35 & 7.60 & 70.10 & 2.83 \\
Animal debris & 13.51 & 10.48 & 4.35 & 46.44 & 6.05 & 200.51 & 8.11 \\
Crabs & 1.35 & 0.80 & 0.09 & 55.55 & 7.24 & 1.22 & 0.05 \\
Shrimp & 1.35 & 0.80 & 0.07 & 41.66 & 5.43 & 1.18 & 0.05 \\
Insects & 1.35 & 0.80 & 0.05 & 5.43 & 0.71 & 1.15 & 0.04 \\
plants & 2.70 & 3.22 & 1.13 & 60.41 & 7.87 & 11.76 & 0.47 \\
Fruits & 8.11 & 11.29 & 0.09 & 0.45 & 0.06 & 92.28 & 3.73 \\
\hline
\end{tabular}

Table II. Diet of Galeoides decadactylus. Percentage of occurrence (O), Numerical percentage $(\mathrm{N})$, Weigh percentage $(\mathrm{W})$, index of relative importance (IRI) and specific index of abundance $(\mathrm{Si})$ of prey families.

\begin{tabular}{llllllll}
\hline Family & $\mathrm{O}$ & $\mathrm{N}$ & $\mathrm{W}$ & $\mathrm{Si}$ & $\% \mathrm{Si}$ & IRI & $\%$ IRI \\
\hline Penaeidae & 31.16 & 53.66 & 47.30 & 57.27 & 11.33 & 3146.17 & 75.52 \\
Palaemonidae & 10.14 & 11.14 & 14.60 & 41.50 & 8.21 & 261.18 & 6.27 \\
Pasiphaeidae & 3.62 & 3.22 & 3.69 & 20.45 & 4.05 & 25.09 & 0.60 \\
Sicyoniidae & 6.52 & 8.50 & 14.33 & 45.92 & 9.08 & 148.92 & 3.57 \\
Aristeidae & 0.72 & 0.58 & 1.17 & 11.71 & 2.32 & 1.27 & 0.03 \\
Solenoceridae & 0.72 & 0.58 & 0.18 & 12.5 & 2.47 & 0.55 & 0.01 \\
Nematocarcinidae & 0.72 & 0.58 & 0.31 & 13.28 & 2.62 & 0.64 & 0.01 \\
Pandalidae & 1.45 & 0.58 & 1.29 & 16.59 & 3.28 & 2.73 & 0.06 \\
Hippolytidae & 0.72 & 0.88 & 0.21 & 30 & 5.93 & 0.79 & 0.02 \\
Portunidae & 3.62 & 2.93 & 6.33 & 33.62 & 6.65 & 33.57 & 0.80 \\
Lysiosquillidae & 1.45 & 0.88 & 1.26 & 63.06 & 12.48 & 3.10 & 0.07
\end{tabular}




\begin{tabular}{llllllll} 
Squillidae & 1.45 & 0.58 & 1.04 & 29.29 & 5.79 & 2.36 & 0.05 \\
Echinoderme & 0.72 & 0.29 & 0.52 & 28.43 & 5.62 & 0.59 & 0.01 \\
Octopodidae & 2.17 & 0.88 & 2.52 & 46.66 & 9.23 & 7.40 & 0.17 \\
Mytilidae (bivalv) & 0.72 & 0.29 & 0.05 & 1.56 & 0.31 & 0.25 & 0.01 \\
Arcidae (bivalv) & 0.72 & 0.29 & 0.03 & 1.26 & 0.25 & 0.24 & 0.01 \\
Amphinomidae (worm) & 0.72 & 0.29 & 0.70 & 21.66 & 4.28 & 0.72 & 0.01 \\
Clupeidae & 0.72 & 0.88 & 0.70 & 26 & 5.14 & 1.14 & 0.02 \\
unspecified & 31.88 & 12.90 & 3.69 & 4.39 & 0.87 & 529.20 & 12.70 \\
\hline
\end{tabular}

Table III. Diet of Pentanemus quinquarius. Percentage of occurrence (O), Numerical percentage $(\mathrm{N})$, Weigh percentage $(\mathrm{W})$, index of relative importance (IRI) and specific index of abundance $(\mathrm{Si})$ of prey families.

\begin{tabular}{llllllll}
\hline Family & $\mathrm{O}$ & $\mathrm{N}$ & $\mathrm{W}$ & $\mathrm{Si}$ & $\% \mathrm{Si}$ & IRI & $\%$ IRI \\
\hline Aristeidae & 10.14 & 24.85 & 9.20 & 23.46 & 3.95 & 345.48 & 11.26 \\
Penaeidae & 30.43 & 42.60 & 30.53 & 36.04 & 6.07 & 2225.98 & 72.57 \\
Sicyoniidae & 5.79 & 2.96 & 5.75 & 27.84 & 4.69 & 50.49 & 1.64 \\
Crangonidae & 1.45 & 1.18 & 2.61 & 26.31 & 4.43 & 5.504 & 0.18 \\
Pandalidae & 2.89 & 1.77 & 2.09 & 100 & 16.85 & 11.20 & 0.36 \\
Pasiphaeidae & 2.89 & 2.36 & 4.18 & 61.53 & 10.37 & 18.98 & 0.62 \\
Octopodidae & 2.89 & 1.18 & 10.72 & 93.18 & 15.70 & 34.49 & 1.12 \\
Squillidae & 1.45 & 5.91 & 2.35 & 64.28 & 10.83 & 11.98 & 0.39 \\
Clupeidae & 1.45 & 0.59 & 0.39 & 30 & 5.05 & 1.42 & 0.04 \\
Animal debris & 15.94 & 6.50 & 16.73 & 74.41 & 12.54 & 370.50 & 12.08 \\
Shrimps & 18.84 & 7.69 & 14.37 & 47.01 & 7.92 & 415.83 & 13.55 \\
Plants & 5.79 & 2.36 & 1.04 & 9.30 & 1.56 & 19.78 & 0.64 \\
\hline
\end{tabular}

\section{Food Consumption Estimate}

The daily food consumption curves of the threadfin species indicates a weak correlation between this parameter and the individual weight of fish (Figure 3). That same parameter according to the size and the age of the threadfins are recorded in Table IV. The values obtained are high as the fish evolves in age. Relative yearly consumptions of food $Q / B$, i.e. the consumed quantity $\mathrm{Q}$ per unit of biomass $\mathrm{B}$ are given. They reveal a consumption of $0.124 \mathrm{~T} / \mathrm{Km}^{2} /$ year for Polydactylus quadrifilis, whereas that of Galeoides decadactylus is $0.02 \mathrm{~T} / \mathrm{Km}^{2}$ /year. The specimens of Pentanemus quinquarius consume $0.013 \mathrm{~T} / \mathrm{Km}^{2} /$ year. 

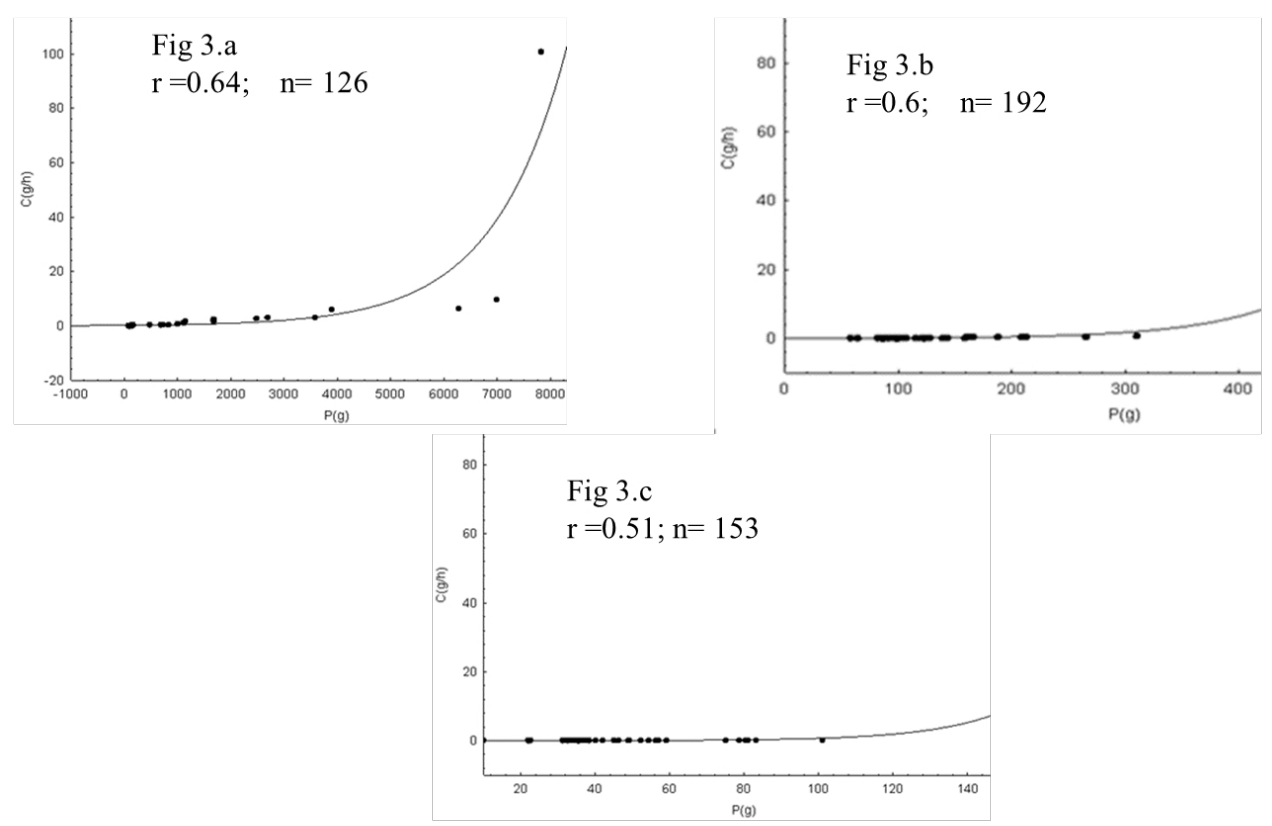

Figure 3. Relation between the daily consumption and the individual weight of the threadfins Polydactylus quadrifilis (3 a.), Galeoides decadactylus (3 b.) and Pentanemus quinquarius (3 c.).

Table IV. Variation of the daily consumptions related to the total $(\mathrm{Lt})$ and the age of the threadfins.

\begin{tabular}{ccc}
\hline Species & $\begin{array}{c}\text { Lt Intervalle } \\
(\mathrm{cm})\end{array}$ & $\begin{array}{c}\text { Consumption } \\
(\mathrm{g})\end{array}$ \\
\hline \multirow{3}{*}{ Polydactylus quadrifilis } & $28-45(<1$ year $)$ & 20.32 \\
& $50-75(1$ year $)$ & 44.8 \\
& $80-100(2$ years $)$ & 148.5 \\
\hline & $17(<1$ year $)$ & 3.82 \\
Galeoides decadactylus & $18-23(1$ year $)$ & 4.32 \\
& $24-28(2$ years $)$ & 6.68 \\
& $29-31$ (3 years) & 13.14 \\
\hline & $18(1$ year $)$ & \\
Pentanemus quinquarius & $19-21(2$ years $)$ & 0.78 \\
& $22(3$ years $)$ & 1.17 \\
& 23 (4 years) & 1.38 \\
& & 2.72 \\
\hline
\end{tabular}

\section{Fish Height- Length of Intestine Relationship}

The relation between the total length $(\mathrm{Lt})$ and the length of the intestine (Li) and also the intestinal coefficient $(\mathrm{Ci})$, determined for threadfins, were recorded in Table $\mathrm{V}$. There is a significant linear relationship between the total 
length of fish and that of the intestine for the specimens of Polydactylus quadrifilis $(\mathrm{p}<0.05)$.

However, correlation is weak between these two parameters according to Galeoides decadactylus and Pentanemus quinquarius (Figure 4). Concerning the intestinal coefficient, the results indicate that threadfins have very short intestines $(\mathrm{Ci}<1)$.
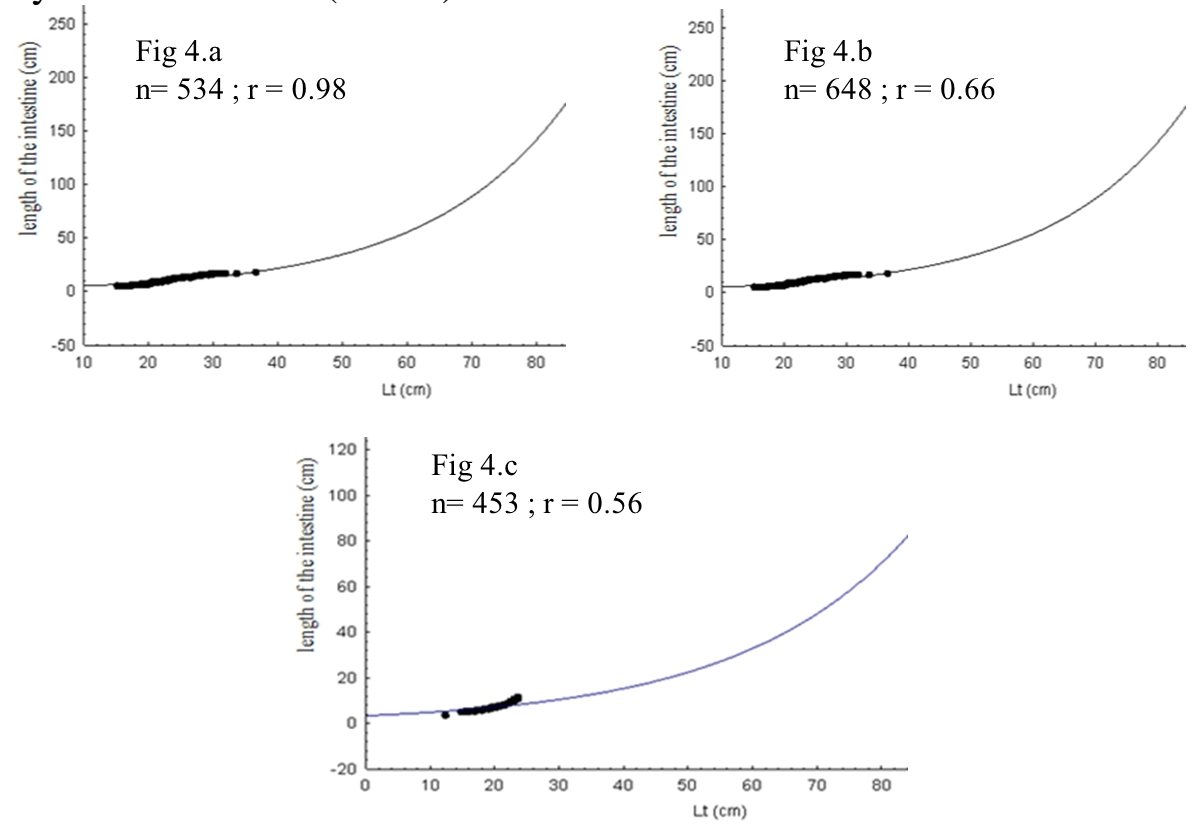

Figure 4. Relation between the length of the intestine (Li) and the total length (Lt) of the threadfins Polydactylus quadrifilis (3 a.), Galeoides decadactylus (3 b.) and Pentanemus quinquarius (3 c.)

Table V. Metric parameters of the digestive system of the threadfins.

(M: male; F: female; Lt: total length; Li: length of the intestine; r: correlation; $\mathrm{p}$ : probability of the Student test.t; IC: intestinal coefficient).

\begin{tabular}{cccccc}
\hline Species & Sexs & Equations & $\mathrm{R}$ & $\mathrm{P}$ (test.t) & $\mathrm{IC}$ \\
\hline \multirow{5}{*}{ Polydactylus quadrifilis } & Males & $\mathrm{Lt}=1.57 \mathrm{Li}-2.9$ & $\mathrm{r}=0.98$ & $\mathrm{p}<0.05$ & $0.828 \pm 0.12$ \\
& Females & $\mathrm{Lt}=1.58 \mathrm{Li}-2.86$ & $\mathrm{r}=0.97$ & $\mathrm{p}<0.05$ & $0.83 \pm 0.11$ \\
& $(\mathrm{M}+\mathrm{F})$ & $\mathrm{Lt}=1.17 \mathrm{Li}-3.54$ & $\mathrm{r}=0.98$ & $\mathrm{p}<0.05$ & $0.83 \pm 0.15$ \\
\hline \multirow{5}{*}{ Galeoides decadactylus } & Males & $\mathrm{Lt}=0.88 \mathrm{Li}-0.31$ & $\mathrm{r}=0.39$ & $\mathrm{p}<0.05$ & $0.55 \pm 0.07$ \\
& Females & $\mathrm{Lt}=0.74 \mathrm{Li}+0.23$ & $\mathrm{r}=0.49$ & $\mathrm{p}<0.05$ & $0.583 \pm 0.08$ \\
& $(\mathrm{M}+\mathrm{F})$ & $\mathrm{Lt}=1.24 \mathrm{Li}-1.36$ & $\mathrm{r}=0.66$ & $\mathrm{p}<0.05$ & $0.587 \pm 0.08$ \\
\hline \multirow{5}{*}{ Pentanemus quinquarius } & Males & $\mathrm{Lt}=0.98 \mathrm{Li}-0.96$ & $\mathrm{r}=0.6$ & $\mathrm{p}<0.05$ & $0.45 \pm 0.06$ \\
& Females & $\mathrm{Lt}=1.02 \mathrm{Li}-1.08$ & $\mathrm{r}=0.58$ & $\mathrm{p}<0.05$ & $0.496 \pm 0.05$ \\
& $\mathrm{M}+\mathrm{F}$ & $\mathrm{Lt}=0.84 \mathrm{Li}-0.44$ & $\mathrm{r}=0.56$ & $\mathrm{p}<0.05$ & $0.49 \pm 0.07$ \\
\hline
\end{tabular}




\section{Trophic Relationships between the Three Species Studied}

The Jaccard community indices are recorded in Table VI. They show a strong similarity of diets between the specimens of Polydactylus quadrifilis and Pentanemus quinquarius (0.85). This similarity is observed between the diets of the Galeoides decadactylus species and Pentanemus quinquarius (0.86). This similarity is avarage between diets of Polydactylus quadrifilis and Galeoides decadactylus (0.67).

Table VI. Jaccard community indices expressing the level of food similarity between studied species.

\begin{tabular}{lccc}
\hline Species & $\begin{array}{c}\text { Polydactylus } \\
\text { quadrifilis }\end{array}$ & $\begin{array}{c}\text { Galeoides } \\
\text { decadactylus }\end{array}$ & $\begin{array}{c}\text { Pentanemus } \\
\text { quinquarius }\end{array}$ \\
\hline Polydactylus quadrifilis & & & \\
Galeoides decadactylus & 0.67 & \\
Pentanemus quinquarius & 0.85 & 0.86 & \\
\hline
\end{tabular}

\section{Discussion}

Results of this research indicate that threadfins appreciate fish and shrimp preys. They confirm those of Gnohossou (2006) in the lake Nokoué in Benin who affirms that Polydactylus quadrifilis is a fish and invertebrates consumer, including shrimps and crabs, which are their essential food. Therefore, the research of Samba (1974) in Congo and Sidibé (2003), on the Guinea maritime coast, showed a prevalence of fish and crustacean in the diet of Polydactylus quadrifilis and Galeoides decadactylus. Albaret (1994) also affirms that diet of Pentanemus quinquarius and Galeoides decadactylus consists of juveniles of fish and mainly of crustacean (shrimps and crabs) in the Ebrié lagoon.

Concerning yearly individual consumption, our results differ from those of Villanueva (2004) who estimated at $8.72 \mathrm{~T} / \mathrm{km}^{2} / \mathrm{year}$, the consumption of crustacean by Polydactylus quadrifilis in the lake Nokoué. Their diet level is 3.2 in this lake and in the Ebrié lagoon too, in Côte d'Ivoire, that positions them at the higher level of the food chains (Villanueva et al., 2003). These fishes show a great plasticity concerning their diet. Therefore, Jones (1954) points out that one should not confuse the food observed in the stomach and the absorbed quantity, insofar as the observation of the specimens at various stages of digestion indicates that the amplitude of the variations of food weight in the stomach is very high. Moreover, one should not reject the possibility of a partial regurgitation because, according to Bowman (1986), it is very probable that under these conditions, calculations lead to an undervaluation of the consumption. So, we need to consider the point of view of Daan (1973) who affirms that the food observed in the stomachs has, on average, lost half of its weight. Thus, the results should be multiplied by a 
factor of about 1.38, if we want to take into account the estimated initial weight. Dubuit (1987) considers that a more realistic estimate of the absorbed quantities would require more precisely to know the food behavior of the species and interpretation to give to the vacuity coefficient. The question is to know if there are really periods of rest or fast? In this case, the vacuity coefficient represents a proportion of the population to be necessarily taken into account in the calculation of the stock consumption, or the vacuity is a passing phase which does not intervene on the final result.

The daily food consumption of threadfins indicates a weak correlation between this parameter and the individual weight of fish. However, the daily consumptions are high as the fish size evolves. That would indicate that the physiological needs of the threadfins would be related to their size and not their weight. According to Guichard (2000), digestion is related to the size of fish for the carnivores. He affirms that the disintegration of solid foods takes place in the stomach, whose volume is proportional to the total length of the fish and is carried out by powerful peristaltic contractions associated with a chemical digestion by the hydrochloric acid and pepsinogene. This, therefore, leads to the formation of the gastric chyme, which passes through the intestine.

The juveniles of Polydactylus quadrifilis have equivalent number of intestinal filaments with those of Galeoides decadactylus and those of Pentanemus quinquarius. The increase of the intestinal filaments number would be due to energy needs of the animal, because the intestinal absorption would vary with the number of these filaments. Threadfins have a relatively short intestine and a strong stomach in which the digestion is mainly performed. In comparison to the results of N'guessan et al. (2010), these fish obviously seem to be voracious species relatively to the intestinal coefficients obtained (IC<1). The values of the intestinal coefficients obtained cover those obtained by Paugy (1994) for omnivorous species. A significant linear relation exists between the length of the intestine and the total length of Polydactylus quadrifilis. However, the correlation is weak between these two parameters for Galeoides decadactylus and Pentanemus quinquarius. These results would be the consequence of the diet variation of Polydactylus quadrifilis according to their stage of development. Indeed, the juveniles of Polydactylus quadrifilis prefer shrimps, whereas the adults consumes fish whose height were mainly being able to reach $30 \mathrm{~cm}$ length. As for the diet of Galeoides decadactylus and Pentanemus quinquarius, they are dominated by the shrimps which are of smaller height, compared to the fish. The variation of the size of the Polydactylus quadrifilis intestine would be due to its adaptation to the feeding mode adopted during the life of this fish. However, the constancy of the diet of Galeoides decadactylus and Pentanemus quinquarius would explain the weak correlation between their total length and that of their intestine. Consumption of fish, shrimp, and other 
crustacean preys by threadfins take into account the capabilities of their stomach and intestine.

\section{Conclusion}

The juveniles of Polydactylus quadrifilis prefer shrimp, whereas the adult ones mainly consume fish of height that can reach $30 \mathrm{~cm}$ long. As for the specimens of Galeoides decadactylus and Pentanemus quinquarius, their diet are dominated by the shrimp which are smaller in height, compared to the fish. The number of intestinal filaments of Galeoides decadactylus and Pentanemus quinquarius is equivalent to those of the juveniles of Polydactylus quadrifilis. Threadfins have a very strong stomach where the digestion is mainly performed. They obviously seem to be voracious species whose daily consumptions are higher as the fish evolves in height.

\section{References:}

1. Albaret, J.J. (1994). Les poisons: Biologie et peuplements. In J-R. Durand et al Editions.Environnement et ressources aquatiques de Côte d'Ivoire. Tome II Les milieux lagunaires, pp 239-274.

2. Bellemans, M., Sagna, A., Fischer, W., \& Scialabba, N. (1988). Fiches FAO d'identification des espèces pour les besoins de la pêche. Guide des ressources halieutiques du Sénégal et de la Gambie (espèces marines et d'eaux saumâtres). FAO, Rome, p 227.

3. Bouchon, C. (1997). Faune, flore, monde marin. Editions Caraïbes, p 208.

4. Coulibaly, N.D. (2003). Relation taille-poids de onze espèces de poissons du Burkina Fasso. In: ACP-EU Fish. Res. Rep., (14): pp 2022.

5. Bowman, R.E. (1986). Effect of regurgitation on stomach content data of marine fishes. Env. Biol. Fish., (16): pp 171-181.

6. Cruz-escalona, V.H., Abitia-cardenes, L.A., Campos-davila, L., \& Galvan-Magana, F. (2000). Trophic interrelations of the three most abundant fish species from laguna San Ignacio. Baja California Sur, Mexico. Bull. of mar. sci., pp 361-373.

7. Daan, N. (1973). A quantitative analysis of the food intake of North Sea cod. Neth. J. Sea. Res., (6); pp 479-517.

8. Defaye, D. (1998). Atlas et bibliographie des crustacés branchiopodes (Anostraca, Notostraca, Spinicaudata, de France métropolitaine. Ed. Muséum national d'Histoire Naturelle, Paris, pp 40-55.

9. Du Buit, M.H. (1996). Diet of hake (Merluccius merluccius) in the Celtic Sea. Fisheries research (28), pp 381-394.

10. Du Buit, M.H. (1987), Alimentation du merlan Merlangius merlangus L. en mer Celtique. Rev. Trav. Inst. Pêches marit., 49: pp 5-12. 
11. FAO (2008). Profil de pêche en Côte d'Ivoire 2007, p 43.

12. Fischer, W., Bianchi, G., \& Scott, W.B. (1981). FAO species identification Sheets for fishery. Eastern Central Atlantic, fishing areas 34, 47 (in part). Canada Funds-in-Trust.

13. Ottawa, Department of fisheries and oceans Canada, by arrangement with the Food and Agriculture Organization of the United Nations, $p$ 310 .

14. Gnohossou, P.M. (2006). La faune benthique d'une lagune ouest africaine; le lac Nokoué au Bénin: diversité, abondance, variations temporelles et spatiales, place dans la chaine trophique. Thèse de doctorat, Institut National Polytechnique de Toulouse, France, 162 p.

15. Guichard, B. (2000). Devenir d'un aliment médicamenteux dans le tractus digestif du turbot (Psetta maxima L. 1758) pour l'étude des rejets d'un antibactérien en pisciculture marine. Thèse Ecol. Nat. Vétern . de Nantes, pp 28-34.

16. Jones, M.R.L. (2008). Dietary analysis of Coryphaenoides serrulatus, C. subserrulatus and several other species of macrourid fish (Pisces: Macrouridae) from northeastern Chatham Rise, New Zealand. New Zealand Journal of Marine and Freshwater Research 42, pp 73-84.

17. Jones, R. (1978). Estimates of the food consumption of haddock (Melanogrammus aeglejinus) and cod (Gadus morhua). J. Cons, inter. Explor. Mer, pp 18-27.

18. Jones, R. (1954). The food of the whiting and comparison with that of the haddock. Mar. Res. Scot. Home Dept., (2): pp 25-34.

19. Konan, K. S., Diaby, M., Agnissan, A. J. P., Koné, A., \& N’da, K. (2012). Croissance et âge poissons capitaines: Polydactylus quadrifilis (Cuvier, 1829), Galeoides decadactylus (Bloch, 1795) et Pentanemus quinquarius (Linné, 1758) de la pêcherie artisanale maritime de Grand-Lahou (Côte d'Ivoire). Int. J. Biol. Chem. Sci. 6 (3): pp 11121127.

20. Lalèyè, P., Chikou, A., Philippart, J.C., Teugels, G., \& Vandewalle, P. (2004). Étude de la diversité ichtyologique du bassin du fleuve Ouémé au Bénin, Cybium 2004: pp 329-339.

21. Motomura, K. \& Iwatsuki, (2002). Threadfins of the World, FAO Species Catalogue for Fishery Purposes No. 3, pp 65-71.

22. N'guessan, N.Y.S., Doumbia, L., N'goran, K.G., \& Gourene, G. (2010). Habitudes Alimentaires du Poisson-chat, Clarias Anguillaris (Linné, 1758); Clariidae dans un Hydrosystème Fluvio-lacustre ouestAfricain (Rivière Bia, Côte d'Ivoire). European Journal of Scientific Research, Vol.46 No.2, pp 275-285.

23. Palomares, M.L.D. \& Pauly, D. (1998). Predicting food consumption of fish populations as functions of mortality, food type, 
morphometrics, temperature and salinity. Marine and Freshwater Resources 49: pp 447-453.

24. Palomares, M.L. \& Pauly, D. (1989). A multiple regression model for predicting the food consumption of marine fish populations. Australian Journal of Marine and Freshwater Resources 40: pp 259-273.

25. Paugy, D. (1994). Ecologie des poissons tropicaux d'un cours d'eau temporaire (Baoulé, haut bassin du Sénégal au Mali): adaptation au milieu et plasticité du régime alimentaire. Rev. Hydrobiol. trop. (27): pp 157-172.

26. Paugy, D. \& Leveque, C. (1999). Régimes alimentaires et réseaux trophiques. In : Lévêque C. et Paugy D. (Eds.) : Les poissons des eaux continentales africaines, p 156.

27. Pinkas, L., Oliphant, M. S., \& Iverson, I. L. K. (1971). Foods habits of albacore, bluefi $\mathrm{n}$ tuna and bonito in California waters. Calif.Fish \& Game; p 152

28. Samba, G. (1974). Contribution à l'étude de la biologie et de la dynamique d'un Polynemidae ouest africain Galeoides decadactylus (Boch., 1795). Thèse de 3e cycle, Université de Bordeaux I, France p 114.

29. Schneider, W. (1990). FAO species identification sheets for fishery purposes. Field guide to the commercial marine resources of the Gulf of Guinea. Prepared and published with the support of the FAO Regional Office for Africa. Rome, FAO.1990, p 268.

30. Sidibé, A. (2003). Les ressources halieutiques démersales côtières de la Guinée: exploitation, biologie et dynamique des principales espèces de la communauté à sciaénidés. Thèse de doctorat halieutique ENSARennes, p 320.

31. Tachet, H., Richoux, P., Bournaud, M., \& Usseglio-Polatera, P. (2003). Invertébrés d'eau douce: systématique, biologie, écologie. CNRS (Ed.), Paris, p 587.

32. Villanueva, M.C.S. (2004). Biodiversité et relations trophiques dans quelques milieux estuariens et lagunaires de l'Afrique de l'Ouest: Adaptation aux pressions environnementales. Thèse de doctorat, I.N.P. Ecole Nationale Supérieure Agronomique de Toulouse, France, pp 7072.

33. Villanueva, M.C.S., Lalèyè, P., Laë, R., Albaret, J.J., Tito De Morais, L., Simier, M., \& Moreau, J. (2003). Preliminary trophic models of two West African Coastal Lagoons, Lagoon Ebrié (Ivory Coast) and Lake Nokoué (Bénin). Abstract. 3rd International Conference of the Pan African Fisheries society, Cotonou (Bénin), 10-14 Nov. 2003, pp 153-155. 